O. S. Kolesnyk, Doctor of Cultural Studies, associative professor, Professor of National T. G. Shevchenko University "Chernihiv Colleguim», Chernihiv elenakolesnyk2017@gmail.com https://orcid.org/000-0002-0597-6489

\title{
HERMENEUTICS OF THRILLER: FROM WILLIAM SHAKESPEARE TO DAN BROWN
}

The author analyzes some philosophical subtexts of popular culture. As a result, we show the immanent presence of the hermeneutic problematics in the genre of thriller, and define some tendencies in its development. The hermeneutic problematics of a thriller is multilayered, some thrillers have «anagogical» level, treating the world itself as the text to be deciphered. This refers to the medieval hermeneutic tradition. Some of Shakespeare's works can be seen as proto-thrillers with considerable hermeneutic potential; he has also introduced a set of character-types, used in almost every thriller since. The next stage of development of the hermeneutic problematics within the genre is found in the works of John Buchan. Nowadays emerges a new sub-genre of culturological thriller, popularized by Dan Brown.

Key words: hermeneutics, thriller, Shakespeare, John Buchan, Dan Brown.

О. С. Колесник, доктор культурології, доцент, Національний університет «Чернігівський колегіум» імені Т. Г. Шевченка, м. Чернігів

\section{ГЕРМЕНЕВТИКА ТРИЛЕРА: ВІД ВІЛЬЯМА ШЕКСПІРА ДО ДЕНА БРАУНА}

Актуальність. Одним з важливих напрямів сучасної культурології є винайдення філософських підтекстів популярної культури.

Мета статті - висвітлити іманентну наявність герменевтичної проблематики в жанрі трилера, а також визначити деякі тенденції її розкриття.

Методологія. Для дослідження використано метод культурологічної герменевтики, доповнений сумісними з ними методологіями, такими як аналітична психологія.

Результати. У результаті дослідження виявлено, що герменевтика трилера багатоаспектна. Основними її рівнями вважають: 1. Самоусвідомлення протагоніста; 2. Необхідність для героя зрозуміти свого ворога та його дії; 3. Розуміння певного політичного та соціокультурного контексту; 4. Деякі трилери мають «анагогічний» рівень, де світ тлумачиться як текст, який необхідно розшифрувати. У трагедіях Шекспір запровадив набір актантів, який досі використовують практично в усіх трилерах, незалежно від виду мистецтва; деякі його твори вважають «прото-трилерами» зі значним герменевтичним потенціалом. Наступний етап розвитку герменевтичної проблематики в жанрі пов'язаний з творчістю Дж. Бакена. Нині виникає піджанр «культурологічного трилера», популяризованого Деном Брауном.

Новизна. Стаття $€$ першою спробою встановлення нової культурологічної проблематики (імпліцитна філософська основа конкретного мистецького жанру), визначення форм та тенденцій «герменевтики трилера». 
Практичне значення. Матеріали і результати роботи можна використовувати під час підготовки курсів лекцій з історії та теорії світової культури.

Висновки. Трилер як жанр основується на вираженій герменевтичній проблематиці. Від протагоніста вимагається усвідомити власну ідентичність, характер та мотиви своїх супротивників, загальну ситуацію в суспільстві, інколи - світ в цілому. Серед тем, які потребують подальшого дослідження, - вплив Шекспіра на сучасну популярну культуру; вивчення спадщини Дж. Бакена; подальший розвиток концепту «культурологічний трилер».

Ключові слова: герменевтика, трилер, Шекспір, Джон Бакен, Ден Браун.

Е. С. Колесник, доктор культурологии, доцент, профессор кафедры философии и культурологии Национального университета «Черниговский коллегиум» имени Т. Г.Шевченко, г. Чернигов

\section{ГЕРМЕНЕВТИКА ТРИЛЛЕРА: ОТ УИЛЬЯМА ШЕКСПИРА ДО ДЭНА БРАУНА}

Одним из важных направлений современной культурологии является определение философских подтекстов популярной культуры. Освещается имманентное наличие герменевтической проблематики в жанре триллера, прослеживаются некоторые тенденции ее развития. Герменевтика триллера многоаспектна: 1. Самоосознание протагониста; 2. Необходимость для героя понять своего врага и его действия; 3. Постижение определенного политического и социокультурного контекста; 4. Некоторые триллеры имеют «анагогический» уровень, где мир толкуется как текст, подлежащий расшифровке. Шекспир ввел набор актантов, до сих пор использующийся практически во всех триллерах; некоторые его произведения предстают «прото-триллерами» со значительным герменевтическим потенциалом. В наше время возникает поджанр «культурологического триллера», популяризированного Дэном Брауном. В целом проявления герменевтической проблематики в триллере как жанре и в его конкретных произведениях дают значительный материал для дальнейшего исследования.

Ключевые слова: герменевтика, триллер, Шекспир, Джон Бакен, Дэн Браун.

The relevance of the theme. For a long time popular literature was treated as culturally and aesthetically inferior, lacking depth and philosophical insights. Now it became a respectable field of study. One of the important areas of research is identifying the philosophical subtexts of works of fiction. The theoretical value of this research is deeper understanding of cultural processes in a society and in the whole world. The practical significance is in the possibility of more adequate evaluation of specific works of art and whole cultural tendencies.

Problem statement. There is a need to show the philosophical themes underlying the works of popular culture, namely in the genre of thriller.

Previous research. The literature about the history and theory of thriller and related genres, especially detective stories is quite extensive. The 
philosophical subtexts were most successfully analyzed by G. K. Chesterton (Chesterton G. K. A Defence of Detective Stories), who described its religious subtexts, and by D. Kluger (Клугер, 2005), and K. Summerscale Summerscale (2008), who stressed the mythopoetic parallels. The most prominent contemporary Ukrainian researchers are L. Hamburg (Гамбург, 2016) and G. Krapivnyk (Крапівник, 2015). It is possible to use their factual material and methodology for further research of the theme.

The aim of the research is to show the immanent presence of the hermeneutic problematics in the genre of the thriller, and to define some tendencies in its development.

The hermeneutics of thriller. It is usually considered that thriller in the strict sense of the word emerged in the early 20th cen. However, different forms of «proto-thriller» preceded the formation of the genre.

The etymology of the word «thriller» is transparent. It characterizes the pleasantly apprehensive state of the reader, rather than the theme, plot or structure of the work itself. A number of texts can fit a loose definition of the thriller. The borderlines are not clear, as there is much overlapping with drama, romance, adventure, action, police and spy novel. The closest links exist between thriller and crime novel; sometimes the same books can be classified both ways. The main difference is that detective story is preoccupied with the past, its main question is «who has done it?» (hence whodunit). The thriller is more interested in the future, as the action comes to a catastrophic conclusion. The struggle of the characters is often complicated by the race against time. The stakes are extremely high; the protagonist often has to save the country, or even the world. A typical feature of thriller is presentation of the story from the point of view of a victim or a criminal (or even victimcriminal).

Usage of the term «hermeneutics» when speaking about the genre of thriller works in a number of ways:

Hermeneutics as a methodology can be applied to any text.

Any author of a thriller tries to understand the perspective audience, and offers a text that would satisfy their hidden desires. Doing this the author more or less consciously uses principles of hermeneutics.

Elements of hermeneutics are present in the act of artistic interpretation such as illustration, scene- or screen adaptation of a literary work.

The thriller has inner hermeneutic problematics, as their authors and characters strive to understand complicated things. This is the theme of our research.

The hermeneutic problematics of a well-written thriller is multi-layered. The first of these interconnected levels is self-realization of a protagonist. Often the hero is ejected from normal life, and becomes an outcast. Losing 
everything that was seen as essential - the way of life, social status and connections, sometimes even name and memory - he / she retains only the «essence» of personality. This can lead to a deeper understanding of the Self and to the possibility of personality re-creating.

Typical for the thriller is the hero's need to understand the enemy. One of the sub-genres depicts the deadly game of protagonist with a clever maniac who must be understood to be neutralized. Often such a game demands from the detective diving into his/her own traumatic past and confronting «own demons». This is close to Schleiermacher's tradition of hermeneutics. Detective and criminal can be seen as symbolic «twins». This idea was clearly expressed by G. K. Chesterton in The Secret of Father Brown, where the eponymous hero states: «You see, it was I who killed all those people ... I had thought out exactly how a thing like that could be done, and in what style or state of mind a man could really do it. And when I was quite sure that I felt exactly like the murderer myself, of course I knew who he was» (Chesterton).

The next hermeneutic level is understanding of a certain social, political and cultural context. For the hero this is vital for survival. For the author it is the way to communicate some information, or even some philosophical conception to the reader. For example, in B. Akunin's Leviathan, the hero's understanding of the Japanese culture allows him to explain a Japanese gentleman's seemingly odd behavior and thus save him from accusation. Meanwhile, the reader learns something about Oriental culture.

Lastly, some thrillers have the «anagogical» level, treating the world itself as a text to be deciphered. It is seen in the works of a Christian Platonist G. K. Chesterton, namely, in his The Man Who Was Thursday. Sometimes an author purposefully constructs this level of meaning. But there is also the immanent metaphysics of the genre. The mythopoetics sees the crime as a violation of the world order with grave consequences, and vice versa, when there is a disaster we must find a hidden crime, as shown in the story of Oedipus. D. Kluger, whose research has a telling title - The Baskerville Mystery, studied the metaphysical subtext of detective. The same principles can be applied to the study of the thriller.

Shakespearean tragedies as «proto-thrillers». If we use the «loose» definition of thriller, many Shakespeare's works would qualify. The four so-called Great tragedies (Hamlet, Othello, King Lear, and Macbeth) and some other works, introduce a set of character-types. Their interaction creates a highly flexible structure, any variant of which builds great suspense and leads to an unforgettable climax. Here is the list of the actants, invented by Shakespeare, and used in almost every thriller since. 
The Intriguer - the main evildoer and the dynamo of the plot. He is the criminal mastermind, tempter and manipulator. Often he has a special bond (blood relation etc.) with his victim, which makes his actions all the more treacherous. His personal qualities differ, ranging from demonic villain (Iago) to flawed tragic hero (Macbeth). He always dies, and sometimes this death is a kind of atonement.

The Fatal woman - the Intriguer's wife or lover. She can also be «fiendlike» or a victim of the fate, whose guilt was redeemed (Gertrude, Emilia).

The Heroine - a young woman «too good» for the sinful world. In Shakespearean tragedies she always dies, but later thrillers tend to save her.

The Victim. Usually an older man, whose high status the Intriguer wants to usurp. The plot can begin with his death, but this character remains important even in death, as seen on example of Hamlet Senior.

The Instrument - a person, who commits crimes for the Intriguer's benefit. Sometimes he is a servant who obeys a criminal order. In other cases he is a noble person, whose passion is twisted by a manipulator (Othello). If so, he can understand his role and turn against his real enemy. It allows him to expiate his crime.

The Framed one - a young man, accused of a crime or otherwise dispossessed by the Intriguer. Usually he defeats the enemies and restores the justice. In the later thrillers, this type has transformed into «the Third» - a loner between two equally unjust sides. This character is in the hallmark of a sub-genre that includes spaghetti-westerns, samurai films, and gangster movies. Such films as Yojimbo, The Fistful of Dollars, Django, Last Man Standing, Once Upon a Time in Mexico, Lucky Number Slevin, Bunraku, etc. are the variants of the same plot.

The most typical example of Shakespearean proto-thriller is the socalled subplot of Gloucester and his sons in King Lear. The situation Edgar finds himself in, is one of the first examples of the theme «the man vs the system», where an innocent person is pitted both against the criminals and against the law.

An outcast meets the problems of personal and generic identity and becomes an example for studying such dichotomies as «to be or to have», and «to be or to seem». In the context of Ontological Hermeneutics, the whole tragedy is an experiment that should clarify the essence of human being. The heroes undergo a number of sequencings abstractions - they lose social status, family ties, property, clothing, and even sanity. They become «unaccommodated men», reduced to the invariant essence that cannot be alienated. This kind of eidetic reduction helps the characters and the recipients to understand the real nature of a person - and of humanity as a whole. 
In King Lear Shakespeare studies such philosophical category as Nothing. Both Lear and Edgar have nothing, owe nothing. However, a person who become nothing and nobody can become anybody and everybody. The theme of personality transformations is closely connected to the theme of change (or absence) of name. In King Lear Edgar must turn into mad Tom, not just assuming a role, but also drastically changing his personality. The popular culture of the last 200 years re-mythologized the absence of name or usage of a pseudonym. In a number of thrillers - from E. Childers's The Riddle of the Sands (1903) to T. Hayes's I Am Pilgrim (2012) - the main character's real name remains hidden. This mystery hints at the complexity of both human being and the world. The most interesting development of the theme of name change we find in R. Ludlum's The Bourne Identity. The book investigates such themes as re-establishing person's identity, finding the lost memory and connection to the previous life. The theme of amnesia was misused in the popular culture, but it still hints at Platonic anamnesis - as the search for the lost homeland of the soul.

John Buchan and the formation of the thriller genre. The problem of soul and its powers is one of the central for J. Buchan - a politician and diplomat, who was one of the fathers of the thriller in the strict generic sense of the word.

One of the recurrent themes in his novels is the mysterious ambiguity of the world and all its manifestations. The good and the evil are sometimes undistinguishable, and the most important things are hidden under «the blanket of the dark» (the title of his novel). Much attention is attached to the unconscious. Sometimes it is seen as treacherous, apt to be enslaved by the almost-irresistible charisma of a great villain. But in other cases the forces of the subconscious can be harnessed and used.

The most popular of Buchan's novels, The Thirty-Nine Steps, is one of the first modern thrillers. Here - perhaps for the first time since Shakespeare we see the situation that later has become a cliché: a man on the run, pursued by both the police and the criminals and racing against time to prevent a great blow to his country's security. The seemingly simple text is in fact multi-layered. From the hermeneutic point of view, there are three especially interesting points. The first is the motif of «the dead man's letter» that must be deciphered. The second - transformations of the protagonist, who is able not to play, but to live a chosen role to hide from his enemies. The third is the need to understand the enemy to predict his action.

In Greenmantle, the sequel to The Thirty-Nine Steps, appears the theme of essence and appearance, exemplified by the motif of clothing. Clothes of different kinds become instruments of disguise and of personality change. 
They also have their own significance, namely - religious, the eponymous «green mantle» being the relic of an Islamic leader, able to command a jihad.

The next book in the series, Mr. Standfast, introduces still another topic. Here spies use Bunyan's The Pilgrim's Progress as a codebook, but it is also seen as a key to the reality. For the characters the world appears as a text, full of meaning. They try to identify with Bunyan's characters, and in that way understand themselves and their own trials. The same all-pervading symbolism we also find in T. Hayes's I Am Pilgrim.

Perhaps the most hermeneutically rich of Buchan's novels is The Three Hostages. It is extraordinarily complex and worthy of a separate research. One of its levels is the deep exploration of the unconscious. The author mentions S. Freud, but is not satisfied with his method. Buchan starts with comparatively simple problems - how to manage subconscious to remember forgotten things, to connect different disparate things etc. Then he moves to the question of identity and self-knowledge. Still deeper are the theme of «dominance of spirit upon spirit», where he presages the rise of «charismatic» political leaders in the XX ct. and its catastrophic results. Here we see such topics as hypnosis, provocation and propaganda, misuse of religion and ideology. The enemy is the stranger, who infiltrated into the upper society using mimicry. The protagonists can also play this game. Their main difference is in the aims: the villain wants power over the souls. The heroes work to free his victims. Still, there is a connection between them. They are students of the same arts. Tellingly, the word, which serves as a clue that helps to uncover the villain's plot, is «hermeneuma».

Buchan's characters use three types of identity changes. Interestingly, all of them we can also see in Shakespeare's plays.

1) Melting into the world. A person can blend with the landscape or cityscape, and become unnoticeable. To do this one must understand human psychology and make use of its blind spots.

2) Pretense: a character assumes false attitudes, feelings, views, state of mind (Hamlet playing madness) or even ontological status (Juliet playing death).

3) Metamorphosis: a character creates a completely different persona. The key to the success is not to play, but to live the role. In The Three Hostages one of the characters, who is able to become unrecognizable to his closest friends, says: «... the human personality is identified far less by the appearance than by its habits and mind. Loss of memory means the loss of all true marks of identification, and the physical look alters to correspond» (Buchan, 2010, p. 678). That is why recognizing a person who has lost memory or adopted a new personality demands special hermeneutical effort. 
The emergence of the «Culturological Thriller». The contemporary thriller combines many sub-genres. Some of them have hermeneutic problematics at their core. Sometimes it is even reflected in the title, as in J. Rubenfeld's The Interpretation of Murder, where S. Freud is cast in the role of a detective.

For quite a long time, the advances of science and technology tempted the authors of thrillers to make use of the new discoveries. This tendency has culminated in M. Crichton's creating the sub-genre of intellectual «technothriller». In the late 20th - early 21 st century writers become attracted not only by the advances of technology, but also by the intricacies of the inner life of culture. The interaction of cultures and traditions, of the past and the present, the problems of hidden heritage and forbidden history that still define people's way of life, all become a new field to study and depict.

The first type is the historical thriller. Its plot structure is more or less traditional, but historical setting demands from the author knowledge of the background and understanding of the «Uhrphaenomen» of the culture. Among the most interesting examples of this kind are the historical spy novels of the professional Orientalist Master Chang. In the historical thrillers, the intrigue sometimes centers on a certain cultural phenomenon, as in U. Eco's The Name of the Rose, or O. Pamuk's My Name is Red.

The second type is characterized by the contemporary characters trying to solve a mystery that spans past and present. For this they need specialist knowledge of history and cultural studies. Often in the center of the plot is a great work of art or a great idea.

The elements of this approach appeared in different times and in different national cultures. For instance, V. Korotkevich's The Black Castle of Olshansky has all the qualifications. The «paradigmatic» examples of the culturological thriller are the works by Dan Brown. His habit of presenting hypotheses as the proved fact is open to questions. Still, the worldwide popularity of his works immensely heightened the prestige of the cultural studies. A number of works inspired by Brown's novels are frankly epigonic. Others, as books by J. L. Carrell, for example, are interesting. Anyway, it is instructive to be present at the birth of a new genre.

Conclusion. The thriller as a genre has a strong hermeneutic problematics at its core. The protagonist needs to understand his / her own identity, the character and motifs of the opponents, the general situation in the society, and sometimes - the world as a whole. Studying the philosophical subtexts of the often-ignored works of popular culture could open a new problem field for the contemporary culturology. Among the themes that deserve further research, are the influence of Shakespeare (and other classics) on the 
contemporary popular culture; studying J. Buchan's legacy; further development of the concept of culturological thriller.

\section{References}

Hamburg, L. (2016). Oh, the Fog of London... An Invitation into the World of the Classical English Detective. Kiev: Raduga [In Russian].

Kluger, D. (2005). The Baskerville Mystery: The History of the Classical Detective. Moscow: Text [In Russian].

Krapivnyk, G. O. (2015). Philosophical-anthropological implications of the detective practices (Abstract of candidate's thesis). Kharkiv: KhNPU [In Ukrainian].

Buchan, J. (2010). The Three Hostages. The Complete Richard Hannay Stories. Wordsworth Classics. 990 p. [In English].

Chesterton, G. K. A Defense of Detective Stories. Retrieved from https//www. chesterton.org/a-defence-of-detective-stories/ [In English].

Chesterton, G. K. The Secret of Father Brown. Retrieved from https://www. wikilivres.ca/wiki /The_Secret_of_Father_Brown/The_Secret_of_ Father_Brown [In English].

Summerscale, K. (2008). The Suspicions of Mr. Whicher, or The Murder at Road Hill House. London: Bloomsbury. 360 p. [In English].

Надійшла до редколегії 02.03.2018 p. 